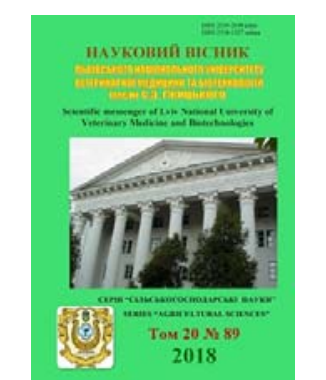

Науковий вісник Яьвівського національного університету ветеринарної медицини та біотехнологій імені С.3. Гжицького

UDC 57.022

\title{
The usage of bioindicators for assessment of the atmospheric air state in the area of the activity of Dobrotvirska Thermal Power Station (TPS)
}

\author{
A.A. Butsyak, V.I. Butsyak, L.I. Muzyka \\ Stepan Gzhytskyi National University of Veterinary Medicine and Biotechnologies Lviv, Ukraine
}

Article info

Received 22.09.2018 Received in revised form 24.10.2018 Accepted 25.10.2018

Stepan Gzhytskyi National University of Veterinary Medicine and Biotechnologies Lviv, Pekarska Str., 50, Lviv, 79010, Ukraine. Tel.: +38-097-121-58-21 E-mail:v.butsyak@gmail.com
Butsyak, A.A., Butsyak, V.I., \& Muzyka, L.I. (2018). The usage of bioindicators for assessment of the atmospheric air state in the area of the activity of Dobrotvirska Thermal Power Station (TPS). Scientific Messenger of Lviv National University of Veterinary Medicine and Biotechnologies, 20(89), 122-126. doi: 10.32718/nvlvet8922

The methodological aspects of the research of the atmospheric air state have been studied, the attention has been paid to biological methods, in particular, to the method of indicating the area of leaf blades, which is easy to use and allows getting reliable results. Taking into account the informative value of the morphometric parameters of the warty birch leaves and the sensitivity of the species to environmental pollution, it is promising to use this species of tree plants as a bioindicator when assessing the ecological status of an urbanized and anthropogenic-transformed environment. The integral index of warty birch leaves asymmetry in the territory with a minimum air pollution was the lowest - 0.0258. The maximum value (0.0914) was investigated in the territory of the "Dobrotvirska Thermal Power Station", which indicates extremely unfavorable conditions; therefore the plants are in a very depressed state. The average integral index of the fluctuating asymmetry for the warty birch in the region of our studies is 0.0586 , which suggests an approximation of the ecological state to precritical level. The comparative analysis of the morphometric parameters of the warty birch leaves discovered their uneven resistance to environmental pollution, which manifests itself by decreasing the size, area and biomass (cell material) of the leaves, as well as by increasing the degree of their necrotic damage

Key words: bioindication, air quality, biotest-objects, warty birch, leaf blades (limbs).

\section{Використання рослинних біоіндикаторів для оцінки стану атмосферного повітря в зоні діяльності Добротвірської ТЕС}

\author{
А.А. Буцяк, В.І. Буцяк, Л.І. Музика
}

Львівський національний університет ветеринарної медицини та біотехнологій імені С.3. Гюиџького, м. Львів, Україна

Вивчено методологічні аспекти дослідження стану атмосферного повітря, акиентовано увагу на біологічних методах, зокрема методі індикачії за площею листових пластинок, який є простим у використанні та дозволяє отримати достовірні результати. Враховуючи інформативність морфометричних параметрів листків берези бородавчастої та чутливість виду до забруднення довкілля, перспективним є використання даного виду деревних рослин як біоіндикатора при оцінці екологічного стану урбанізованого і техногенно-трансформованого середовища. Інтегральний показник асиметрії листків берези бородавчастої на території з мінімальним забрудненням атмосферного повітря був найнижчим - 0,0258. Максимальний показник (0,0914), досліджено на території ВП “Добротвірська ТЕС”, що свідчать про вкрай несприятливі умови, рослини перебувають у сильно пригніченому стані. Середній інтегральний показник флуктуючої асиметрії для берези бородавчастої длянки натих досліджень становить 0,0586, що свідчить про наближення екологічного стану до передкритичного рівня. Порівняльний аналіз морфометричних параметрів листків берези бородавчастої виявив неоднакову їх стійкість до забруднення довкілля, яке проявляється зменшенням розмірів, площі та біомаси листків, а також зростає ступінь ӥхнього некротичного ураження.

Ключові слова: біоіндикаиія, якість повітряного середовища, біотест-об'єкти, береза бородавчаста, листкові пластинки. 


\section{Вступ}

В умовах постійного зростання забруднення навколишнього природного середовища все більшої актуальності набуває проблема якісної експрес-оцінки рівня забруднення компонентів довкілля (Hrubinko, 2005). У зв'язку з цим відбувається широке впровадження методів біоіндикації, які використовуються як експрес-методи для виявлення техногенного навантаження на біоценоз. Метод біоіндикаторів заснований на оцінці стану навколишнього природного середовища за реакціями живих організмів, ці реакції дозволяють оцінити антропогенний вплив на довкілля в показниках, що мають біологічний зміст.

Як біоіндикатори обираються найбільш чутливі до досліджуваних чинників біологічні системи чи організми. Чутливість організмів до змін умов середовища й особливо до наявності конкретних хімічних домішок покладена в основу біологічної індикації, яку використовують поряд з інструментальними методами оцінки забруднення навколишнього природного середовища. Основним завданням біоіндикації $є$ розробка методів і критеріїв, що зможуть адекватно відображати впливи різного характеру з урахуванням комплексних особливостей забруднення та діагностувати ранні порушення у найбільш чутливих компонентах біотичних угруповань (Keivan et al., 2013).

Біоіндикація передбачає цілеспрямоване використання стандартних тест-організмів і методів для визначення якісного стану довкілля. Оцінка повітряного середовища, або інтегральна оцінка якості середовища проживання живих організмів, проводиться на різноманітних об'єктах, в тому числі за станом вищих деревних і трав'янистих форм рослин. Листя у них формується кожен рік, що дозволяє проводити щорічний моніторинг; багато рослинних видів мають масове поширення і чітко виражені ознаки, за якими можливо проводити дослідження. Нарешті, аналіз рослин у складі зелених насаджень надає можливості визначити реакцію відгуку, міри впливу забруднення атмосферного повітря на екосистему.

Ліхеноіндикація як один з найпоширеніших методів біоіндикації при дослідженні впливу стаціонарних джерел на біоту має значний недолік, оскільки викиди від стаціонарних джерел можуть відбуватися на значній висоті: 5-20 м і більше, що спричиняє перенесення їх потоками повітря і осідання на верхньому ярусі рослинності. А вже після їх акумуляції у судинних рослинах (деревах) відбувається їхнє часткове надходження в нижній ярус, де й акумулюються різними видами лишайників (Ashykhmina, 2005).

Крім того, рослини-індикатори не повинні бути занадто чутливими і занадто інертними до забруднення. Необхідно, щоб вони мали достатньо тривалий життєвий цикл і невисоку здатність до авторегуляції. За комплексної та системної оцінки стану атмосферного повітря за сумісній дії різних джерел забруднення, в першу чергу стаціонарних, необхідно використовувати рослини-індикатори з верхнього ярусу.

Метою досліджень було оцінити стан атмосферного повітря у зоні діяльності Добротвірської ТЕС за розміром площі листових пластинок з верхнього ярусу деревної рослинності.

\section{Матеріал і методи досліджень}

Для інтегральної оцінки якості середовища проживання живих організмів використовували метод індикації за розміром площі листових пластинок 3 верхнього ярусу деревної рослинності за площею листових пластинок (Butsiak et al., 2011). Це перспективна методика, оскільки деревні рослини поширені повсюдно (посадки, озеленення), в межах населених пунктів переважно ростуть дерева, які є індикаторами, методика проведення досліджень досить проста, дозволяє швидко отримати показові дані.

Найбільш чутливим органом деревних рослин $\epsilon$ зелений листок рослини. Тому для біоіндикації найкращим вегетативним органом є саме листок. Листки схильні до значної мінливості, а діапазон їх норми реакції дуже широкий. Об'єктом дослідження було обрано березу бородавчасту, яка широко розповсюджена в даному регіоні та характеризується чутливістю до дії аеротехногенного забруднення.

Для вимірювання площі листків використовували спосіб, де, знаючи довжину та ширину листка, знаходять коефіцієнт перерахунку, який вираховують за формулами (Butsiak et al., 2011):

$\mathrm{K}=\mathrm{S}_{\mathrm{I}}: \mathrm{S}_{\text {кв }} ; \quad \mathrm{S}_{\mathrm{\pi}}=\mathrm{P}_{л} \times \mathrm{S}_{\text {кв }}: \mathrm{P}_{\text {кв }}$,

де, K - перевідний коефіцієнт;

$\mathrm{S}$ - площа листка (л) або квадрата паперу (кв);

P - маса квадрата паперу (кв) або листа (л).

Вираховування коефіцієнту проводять на основі вимірювання 7-8 листків берези, він дорівнює 0,64. Потім вимірюють довжину (a) та ширину (b) кожного листка і множать на перевідний коефіцієнт (k):

$$
\mathrm{S}=\mathrm{a} \times \mathrm{b} \times \mathrm{k}
$$

На досліджуваній ділянці в серпні-вересні відбирали неушкоджені максимально розвинуті листки в середній частині вегетативних пагонів, що припинили ріст, із середини південного боку крони десяти нормально розвинених дерев берези. Відбір зразків рослинного матеріалу здійснювали з гілок одного порядку галуження нижньої частини крони.

Проби збиралися в 3 точках кожного району, в кожній точці проводилося по 3 вибірки, у кожній вибірці відбирали не менше 50 листків 3 однієї рослини. Потім листки закладалися в гербарні преси, а після повного висушування складалися в картонні коробки 3 номером проби. У вересні-листопаді проводилася лабораторна обробка матеріалу. В дослідженнях була використана система морфологічних ознак для листя деревних культур згідно з методикою "Біотест".

Математичну обробку результатів проводили варіаційно-статистичним методом. Достовірність відмінності одержаних експериментальних даних із контрольними оцінювали за допомогою t-критерію Стьюдента. Всі розрахунки проводили за допомогою редактора MS Excel 2007 та програмного пакета Statistica 6,0 . 


\section{Результати та їх обговорення}

Дослідження показників морфології листків деревних рослин, зокрема їх флюктуючої асиметрії $\epsilon$ перспективним методом біоіндикації стану довкілля. Симетрія є ознакою оптимального стабільного формоутворення, а відхилення від неї - індикатором впливу на рослину стресових факторів. Також варто зазначити, що коефіцієнт флюктуючої асиметрії зростає за зміни життєздатності живих організмів під впливом різних стресових факторів (Luckan and Shadrina, 2013).

Дослідження показали, що ріст і розвиток рослин (дерев), зокрема ріст листкової пластинки значною мірою залежить від навколишнього природного середовища, чим потужніше техногенне навантаження на довкілля, тим більшої шкоди воно завдає біоті. Викиди в атмосферне повітря ВП “Добротвірська ТЕС” одного із найпотужнішого забруднювача у Львівській області з викидами 37543,79 т/р (діоксид азоту 8,32\%, вуглецю оксид 0,62\%, сірки діоксид 79,70\%, інші 0,08\%) - негативно впливають на ріст листків берези, зокрема: довжину черешка $\left(\mathrm{L}_{1}\right)$, листкової пластинки $\left(\mathrm{L}_{2}\right)$, ширину $\left(\mathrm{L}_{3}\right)$ та площу листкової пластинки $(\mathrm{S})$.

Розміри листків берези бородавчастої, які проростали в межах впливу ВП “Добротвірська ТЕС” були відповідно на 2,5, 10,6, 14,8 та 19,3\% меншими порівняно $з$ аналогічними показниками контрольної групи дерев (табл. 1).

Аналіз отриманих результатів (табл. 2) показав, що в зоні мінімального забруднення атмосферного повітря (умовно екологічно чиста зона - с. Стрептів Кам'янка-Бузького району, що відноситься до зони 3 мінімальним техногенним навантаженням) морфологічні параметри листкової пластинки берези бородавчастої перебували в межах значень, характерних для цього виду рослин.

На нашу думку, можна припустити, що в цій зоні умови росту та розвитку берези бородавчастої перебувають майже на рівні природного ареалу. У зв'язку 3 цим отримані значення морфометричних характеристик листків берези бородавчастої нами були використані як умовний контроль.

Таблиця 1

Динаміка зміни параметрів листків берези бородавчастої залежно від інтенсивності техногенного навантаження

\begin{tabular}{|c|c|c|c|c|}
\hline $\begin{array}{l}\text { № } \\
\Pi / \Pi \\
\end{array}$ & $\begin{array}{c}\mathbf{L} 1 \text { (довжина } \\
\text { черешка) }\end{array}$ & $\begin{array}{c}\mathbf{L}_{2} \text { (довжина листкової } \\
\text { пластинки) }\end{array}$ & $\begin{array}{c}\mathbf{L} 3 \text { (ширина листкової } \\
\text { пластинки) } \\
\end{array}$ & $\begin{array}{c}\mathbf{S} \text { (площа листкової плас- } \\
\text { тинки) }\end{array}$ \\
\hline \multicolumn{5}{|c|}{ Місцезростання дерев - умовно екологічно чиста зона } \\
\hline 1 & 1,6 & 5,9 & 4,0 & 15,1 \\
\hline 2 & 2,3 & 7,3 & 6,4 & 29,9 \\
\hline 3 & 1,8 & 6,7 & 5,8 & 24,8 \\
\hline 4 & 2,1 & 5,5 & 4,4 & 15,5 \\
\hline 5 & 2,4 & 5,4 & 5,3 & 18,3 \\
\hline 6 & 2,3 & 5,8 & 5,2 & 19,3 \\
\hline \multirow[t]{2}{*}{7} & 2,1 & 5,6 & 5,3 & 18,9 \\
\hline & 2,08 & 5,98 & 5,02 & 19,2 \\
\hline \multicolumn{5}{|c|}{ Місцезростання дерев - ділянки території ВП “Добротвірська ТЕС” } \\
\hline 1 & 2,0 & 4,9 & 4,1 & 12,4 \\
\hline 2 & 1,7 & 5,2 & 4,0 & 13,6 \\
\hline 3 & 2,2 & 5,7 & 3,6 & 13,1 \\
\hline 4 & 1,8 & 5,7 & 4,5 & 16,7 \\
\hline 5 & 1,8 & 5,4 & 4,4 & 18,7 \\
\hline 6 & 2,1 & 5,1 & 4,8 & 17,2 \\
\hline \multirow[t]{2}{*}{7} & 2,2 & 5,5 & 4,6 & 17,1 \\
\hline & 1,82 & 5,35 & 4,28 & 15,5 \\
\hline
\end{tabular}

Закономірно, що збільшення рівнів забруднення атмосферного повітря негативним чином впливає на морфометричні показники листків берези бородавчастої. Так, в зоні максимального забруднення для всіх показників встановлено зменшення числових значень порівняно зі значеннями, що були отримані в зоні мінімального забруднення.

За нашими даними, мінімальна відмінність показників була встановлена для значень кута між головною жилкою та другою від основи листка жилкою другого порядку, відповідно 97\% для правої половини та 88\% для лівої. Одночасно максимальні відмінності були у значень відстані між основами першої та другої жилок другого порядку (відповідно 83 та 77\%).

У різноманітних екологічних дослідженнях дедалі частіше увагу дослідників привертає проблема асиме- тричного прояву ознак на різних боках білатерально симетричних листкових пластин.

Серед основних типів асиметрії найбільший інтерес викликає флуктуюча асиметрія, яка характеризується невеликими відхиленнями й відсутністю спрямованості.

Дані таблиці 3 свідчать, що інтегральний показник асиметрії листків берези бородавчастої на території 3 мінімальним забрудненням атмосферного повітря $є$ найнижчим - 0,0258.

Максимальний показник асиметрії листкових пластинок берези бородавчастої досліджено на територіях прилеглих до ВП “Добротвірська ТЕС” з показниками флюктуючої асиметрії $(0,0914)$, що свідчать про вкрай несприятливі умови, рослини перебувають у сильно пригніченому стані. 
Таблиця 2

Морфометричні параметри листків берези бородавчастої в умовно екологічно чистій зоні с. Стрептів Кам’янкаБузького району

\begin{tabular}{cccccc}
\hline № & & Параметри & Min & Max & $\mathrm{M} \pm \mathrm{m}$ \\
\hline 1 & I & Л & 18,00 & 31,00 & $22,9 \pm 1,35$ \\
& & $\Pi$ & 19,00 & 31,00 & $23,20 \pm 1,08$ \\
2 & II & Л & 30,00 & 40,00 & $35,42 \pm 1,43$ \\
& & $\Pi$ & 30,00 & 42,00 & $36,23 \pm 1,65$ \\
3 & III & Л & 2,00 & $4,12 \pm 0,38$ \\
& & $\Pi$ & 2,00 & 6,00 & $4,21 \pm 0,43$ \\
4 & IV & Л & 10,00 & 14,00 & $12,26 \pm 0,53$ \\
& & $\Pi$ & 8,00 & 15,00 & $49,62 \pm 0,63$ \\
5 & V & Л & 40,00 & 59,00 & $49,34 \pm 1,01$ \\
& & П & 39,00 & 59,00 & $62,6 \pm 1,88$ \\
\hline
\end{tabular}

Примітка: I - ширина половинки листка, мм; II - довжина другої жилки другого порядку від основи листка, мм; III - відстань між основами першої і другої жилок другого порядку, мм; IV - відстань між кінцями цих жилок, мм; V - кут між головною жилкою і другою від основи жилкою другого порядку, VI - довжина черешка, мм. Л - ліва половинка, П - права половинка

Таблиця 3

Флюктуюча асиметрія листків берези в різних зонах забруднення атмосферного повітря

\begin{tabular}{cccl}
\hline № & Зона забруднення & Флюктуюча асиметрія & \multicolumn{1}{c}{ Екологічна оцінка території } \\
\hline 1 & Мінімальна & 0,0258 & $\begin{array}{l}\text { Умовна норма } \\
\text { Вкрай несприятливі умови, рослини } \\
2\end{array}$ \\
Максимальна & 0,0914 & $\begin{array}{l}\text { перебувають у сильно пригніченому стані } \\
\text { Наближення екологічного стану до максималь- } \\
\text { ного рівня впливу }\end{array}$ \\
\hline
\end{tabular}

Середній інтегральний показник флуктуючої асиметрії для берези бородавчастої району досліджень становить 0,0586, що свідчить про наближення екологічного стану до передкритичного рівня.

Згідно з результатами морфометричного аналізу, в умовах дослідних ділянок спостерігається достовірне зменшення площі, біомаси та лінійних параметрів листків берези бородавчастої щодо контролю, можливо це пов'язано із надмірною кількістю викидів від спалювання природних видів палива на Добротвірській ТЕС, яка розташована в смт. Добротвір (Кам'янкоБузького району).

Основним видом палива є вугілля (некондиційне за зольністю вугілля) з високим вмістом сірчистості та золи, яка за відсутності очистки газової фракції та експлуатації фізично зношеного й морально застарілого пилоочисного обладнання $є$ головним забруднювачем атмосферного повітря Львівської області (2/3 всіх викидів області). Станом на 2016 рік, за інформацією міністерства екології та природних ресурсів, “Добротвірська ТЕС” входить до Переліку 100 найбільших забруднювачів України і $є$ найбільшим забруднювачем атмосферного повітря в Львівській області та джерелом транскордонного переносу забруднюючих речовин.

Найістотніше зменшення площі листкової пластинки берези виявлено на дослідній ділянці - зоні дії промислових комплексів ВП “Добротвірська ТЕС” відповідно на 19,3 з фоновим показником. Значення довжини і ширини листка у межах різнофункціональних ландшафтних зон екосистем є нижчими відносно контролю в середньому на 14\%. Маса листкової пластинки в популяціях берези бородавчастої статистично достовірно знижується у 2,2 разу в зоні дії ВП “Добротвірська ТЕС” щодо цього показника на фоновій території.

\section{Таблиця 4}

Морфометричні параметри листків берези повислої в межах зон дослідження екосистем

\begin{tabular}{lccccc}
\hline \multicolumn{1}{c}{ Досліджувані ділянки } & $\begin{array}{c}\text { Ступінь } \\
\text { некрозу }\end{array}$ & $\begin{array}{c}\text { Площа листка, } \\
\text { см }^{2}\end{array}$ & $\begin{array}{c}\text { Довжина листка, } \\
\text { см }\end{array}$ & $\begin{array}{c}\text { Ширина листка, } \\
\text { см }\end{array}$ & $\begin{array}{c}\text { Біомаса } \\
\text { листка, г }\end{array}$ \\
\hline Умовно екологічно чиста зона & 1,0 & 19,2 & 5,98 & 5,02 & 0,216 \\
Ділянки території ВП “Добротвірська & 3,0 & 15,5 & 5,35 & 4,28 & 0,132 \\
ТЕС” & 2,0 & & \\
\hline
\end{tabular}

Порівняльний аналіз морфометричних параметрів листків берези повислої виявив неоднакову їх стійкість до забруднення довкілля. Зменшення розмірів, площі та біомаси листків берези повислої супрово- джується зростанням ступеня їх некротичного ураження, що посилюється в послідовному ряді досліджених локальних екотопів екосистеми. 


\section{Висновки}

Враховуючи інформативність морфометричних параметрів листків берези бородавчастої та чутливість виду до забруднення довкілля, перспективним є використання даного виду деревних рослин як біоіндикатора при оцінці екологічного стану урбанізованого і техногенно-трансформованого середовища.

Інтегральний показник асиметрії листків берези бородавчастої на території з мінімальним забрудненням атмосферного повітря був найнижчим - 0,0258. Максимальний показник $(0,0914)$, досліджено на тереторії ВП “Добротвірська ТЕС”, що свідчать про вкрай несприятливі умови, рослини перебувають у сильно пригніченому стані. Середній інтегральний показник флуктуючої асиметрії для берези бородавчастої району наших досліджень становить 0,0594, що свідчить про наближення екологічного стану до передкритичного рівня.

Порівняльний аналіз морфометричних параметрів листків берези повислої виявив неоднакову їх стійкість до забруднення довкілля - спостерігається зменшення розмірів, площі та біомаси листків берези повислої, а також зростає ступінь їх некротичного ураження.

Перспективи наукових досліджень. Біоіндикація як важливе доповнення інструментальних методів $є$ найбільш раціональна та ефективна для комплексної експрес оцінки стану забруднення атмосферного повітря урбанізованого середовища, а тому необхідно проводити подальші дослідження щодо використання рослинних біоіндикаторів для діагностики ранніх порушення в найбільш чутливих компонентах біотичних угруповань.

\section{References}

Hrubinko, V.V. (2005). Intehralna otsinka toksychnoho urazhennia u biolohichnykh systemakh. Nauk. zapysky Ternopilskoho pedinstytutu, 26(3), 111-114 (in Ukrainian).

Keivan, M.P. Tertychna, O.V., \& Keivan, O.P. (2013). Vykorystannia roslyn-bioindykatoriv dlia ekolohichnoho otsiniuvannia atmosfernoho povit-ria $\mathrm{v}$ zoni roztashuvannia ptakhofabryky. Naukovyi visnyk NLTU Ukrainy, 22(15), 109-114. http://nbuv.gov.ua/UJRN/nvnltu_2012_22.15_20 (in Ukrainian).

Ashykhmina, T.Ia. (2005). Bioindykatsiia ta biotestuvannia - metody piznannia ekolohichnoho stanu navkolyshnoho seredovyshcha. Kyiv: Znannia (in Ukrainian).

Butsiak, H.A., Cherevko, M.V., Paraniak, R.P., \& Sukhorska, O.P. (2011). Bioindykatsiia. Metodychni vkazivky (in Ukrainian).

Luckan, E.G., \& Shadrina, E.G. (2013). Bioindikacionnaja ocenka sostojanija okruzhajushhej sredy goroda Aldana na osnove analiza fluktuirujushhej asimmetrii berezy ploskolistnoj. Mezhdunarodnyj zhurnal prikladnih i fundamental'nih issledovanij, 8, 139-141. https://applied-research.ru/ru/article/view?id=3793 (in Russian). 